\title{
Tabel Hidup Nyamuk Vektor Filariasis Limfatik Culex quinquefasciatus (Diptera: Culicidae) di Laboratorium
}

\author{
Tri Ramadhani $^{{ }^{*}}$, Vina Yuliani ${ }^{1}$, Upik Kesumawati Hadi ${ }^{2}$, Susi Soviana ${ }^{2}$, Zubaidah Irawati ${ }^{3}$ \\ ${ }^{1}$ Balai Litbang P2B2 Banjarnegara \\ ${ }^{2}$ Laboratorium Entomologi, Departemen Parasitologi dan Entomologi Kedokteran \\ Fakultas Kedokteran Hewan, Institut Pertanian Bogor \\ ${ }^{3}$ Pusat Aplikasi Isotop dan Radiasi (PAIR) - Badan Atom Tenaga Nuklir (BATAN) Indonesia \\ *Corresponding author: 3rdhani@gmail.com
}

Info Artikel : Diterima Desember 2018; Disetujui Agustus 2019 ; Publikasi Oktober 2019

\begin{abstract}
ABSTRAK
Latar belakang: Kelangsungan hidup nyamuk merupakan aspek yang penting dalam penularan penyakit tular vektor. Culex quinquefasciatus merupakan vektor filariasis limfatik yang disebabkan oleh Wuchereria bancrofti. Pengetahuan kehidupan nyamuk berperan penting dalam keberhasilan program pengendalian vektor. Tujuan penelitian ini mendiskripsikan tabel hidup nyamuk $C x$. quinquefasciatus di laboratorium.

Metode: Penelitian diawali dengan koleksi larva $C x$. quinquefasciatus di Kota Pekalongan, kemudian diidentifikasi dan kolonisasi dalam kondisi laboratorium. Parameter yang diukur meliputi masa inkubasi, ekslosi, eksdisis, ketahanan hidup, laju reproduksi, waktu generasi dan laju pertumbuhan intrinsik.

Hasil: Cx. quinquefasciatus mempunyai siklus hidup 12.5 hari. Umur telur, larva, dan pupa masing-masing adalah 2.07; 10.2; dan 2.25 hari. Nyamuk jantan mempunyai ketahanan hidup yang lebih pendek dibandingkan betina. Laju reproduksi bersih (Ro) sebesar 196.75, laju pertumbuhan intrinsik 0.35 dan waktu generasi (T) 14.91 hari.

Simpulan: Pertumbuhan populasi $C x$. quinquefasciatus dapat diatur dan dikendalikan oleh kelulusan hidup dan mortalitas.
\end{abstract}

Kata Kunci : Cx. Quinquefasciatus; tabel hidup; filariasis; laju reproduksi

ABSTRACT

Title: The Live Table of Vector Lymphatic Filariasis Culex quinquefasciatus (Diptera: Culicidae) in the Laboratory

Background: The survival of a mosquito is an important aspect in the transmission of vector borne disease. Culex quinquefasciatus, which is a vector of lymphatic filariasis caused by wuchereria bancrofti. The knowledge of mosquito life is important in providing the foundation for the success of the vector control program. The research aim to describe the life table CX. quinquefasciatus in the laboratory

Methods: This study was originated from the collecting larve of Cx. quinquefasciatus from Pekalongan City, which were then identified and colonized under laboratory conditions. Parameters measured include the incubation period, ekslosi, eksdisis, survival rate, reproduction rate, and generation time.

Results: The results showed that Cx. quinquefasciatus has a 12.5 day life cycle. Egg, larva, and pupa respectively were 2.07; 10.2; and 2.25 days. The males have a shorter survival period compared to the females. The net reproductive rate (Ro) was 196.75; the intrinsic growth rate (rm) was 0.35 and the average generation time (T) was 14.91 days.

Conclusion : The population growth of Culex quinquefasciatus can be regulated and controlled by life graduation and mortality

Keywords:Cx. Quinquefasciatus; life table; filariasis; reproduction rate 


\section{PENDAHULUAN}

Culex quinquefasciatus adalah nyamuk yang umum ada di daerah tropis dan vektor utama filariasis limfatik yang disebabkan wuchereria bancrofti di daerah perkotaan. ${ }^{1}$ Pada tahun 2016 penduduk Indonesia diperkirakan sebanyak 102.279.739 orang hidup di daerah berisiko terinfeksi filariasis. Prevalensi mikrofilaria pada tahun 2015 sebesar 4,7\%, jika penularan di daerah endemis tidak ditangani maka penderita kaki gajah akan bertambah dari 13.032 orang menjadi 4.807 .148 orang. ${ }^{2}$

Salah satu upaya untuk menurunkan prevalensi filarasis limfatik dengan mengendalikan nyamuk $C x$. quinquefasciatus. Upaya pengendalian nyamuk dapat dilakukan dengan pendekatan ekologis. Hal ini berarti bahwa pengendalian harus didasarkan pengetahuan tentang bio-ekologi $C x$. quinquefasciatus. Pemahaman tentang biologi $C x$. quinquefasciatus merupakan prasyarat penting dalam mengembangkan strategi pengendalian vektor yang efektif. Setidaknya untuk melindungi masyarakat terutama dari penularan penyakit tular vektor. Selain itu juga dapat dimanfaatkan untuk mengelola populasi nyamuk secara efektif sehingga berada dibawah ambang batas penularan.

Siklus hidup $C x$. quinquefasciatus terdiri dari empat instar yaitu telur, larva, pupa dan nyamuk dewasa. $\quad C x$. quinquefasciatus betina gravid meletakkan telur secara bergerombol membentuk rakit, dengan rata-rata 155 telur setiap satu siklus gonotrofik. Banyaknya jumlah telur tergantung pada umur nyamuk, sumber darah dan volume darah. ${ }^{3}$ Pada kondisi optimal $\left(30^{\circ} \mathrm{C}\right)$, telur akan menetas menjadi larva dalam waktu tujuh hari, tergantung pada suhu, nutrisi dan kepadatan populasi.

Pada tahapan telur laju pertumbuhannya dipengaruhi oleh pertumbuhaan telur yang menjadi larva, dan terjadi penurunan karena kematian alami dari telur itu sendiri. ${ }^{4}$ Semakin tua umur nyamuk betina maka jumlah telur yang dihasilkan akan semakin berkurang. Penurunan kesuburan terjadi karena adanya degenerasi folikel ovarium dalam setiap siklus gonotrofik, selain itu nyamuk betina tua juga cenderung menghisap darah lebih sedikit dibandingkan dengan nyamuk betina muda. ${ }^{5}$ Penurunan volume darah yang dihisap nyamuk betina tua kemungkinan disebabkan oleh energi yang dimiliki nyamuk betina tua tidak sebaik yang dimiliki nyamuk betina muda. Volume darah yang sedikit dapat menyebabkan penurunan jumlah telur. Menurut Clements (1963) untuk menghasilkan rata-rata 85,5 butir telur, satu nyamuk memerlukan 3-3,5 mg darah, telur tidak dapat dihasilkan bila jumlah darah yang dihisap kurang dari $0,5 \mathrm{mg}{ }^{6}$

Dua sampai tiga hari setelah berada di air telur akan menetas menjadi larva. Larva nyamuk akan mengalami empat masa pertumbuhan (instar I-IV) dan menjadi pupa yang berlangsung selama 8-14 hari. Pada tahapan larva laju pertumbuhannya dipengaruhi oleh pertumbuhaan telur yang menjadi larva kemudian berkurang karena perubahan larva menjadi nyamuk Culex sp dewasa. Laju pertumbuhan larva juga berkurang karena kematian dari larva itu sendiri. Larva hidup di air dan makan bahan organik yang tersedia di air.

Instar pupa merupakan tahap akhir pemberian pakan, di mana pada instar ini organ tubuh sudah mulai dikembangkan menjadi nyamuk dewasa. Bentuk pupa seperti koma dan cenderung tidak aktif, dengan panjang tubuhnya 3,84 $\pm 0,17 \mathrm{~mm}$ dan lebar $1,29+0,14 \mathrm{~mm}^{7}$ Setelah keluar dari pupa dalam waktu dua hari nyamuk betina melakukan perkawinan yang biasanya terjadi pada waktu senja dan kemudian pergi mencari darah untuk pematangan telur.

Nyamuk Culex quinquefasciatus betina dewasa untuk memenuhi kebutuhan protein dalam pembentukan telur memerlukan darah, pemenuhan kebutuhan darah yang biasa diperoleh dari manusia atau binatang yang dilakukan 2-7 hari, ditambah larutan gula selama 1-3 hari. Pada instar dewasa, nyamuk sudah memiliki organ tubuh yang sempurna, dimana pada instar ini berlangsung proses reproduksi yang memberikan sumbangsih besar dalam pertumbuhan populasi nyamuk di alam. ${ }^{8}$

Beberapa faktor lingkungan laboratorium yang dapat berpengaruh terhadap keberhasilan kolonisasi nyamuk yaitu suhu, kelembaban, media air, cahaya, dan $\mathrm{pH}$ air. Kisaran suhu optimum $25^{\circ}-27^{\circ} \mathrm{C}$. Pertumbuhan nyamuk akan berhenti apabila suhu kurang dari $10^{\circ} \mathrm{C}$ atau lebih dari $40^{\circ} \mathrm{C}$. Toleransi terhadap suhu tergantung pada spesies, karena setiap spesies mempunyai respon yang berbeda, namun pada umumnya suatu spesies tidak tahan lama bila suhu lingkungan meninggi $5-6^{\circ} \mathrm{C}$, diatas batas dimana spesies secara normal dapat beradaptasi. ${ }^{9}$

Kompetensi Cx. quinquefasciatus dalam menularkan penyakit dipengaruhi oleh empat faktor yaitu kerentanan terhadap pathogen atau parasit, umur nyamuk, sifat anthrophofilik dan kepadatan relatif. Faktor yang menentukan keberhasilan $C x$. quinquefasciatus untuk menularkan fiariasis limfatik adalah kepadatan yang tinggi, karena memerlukan gigitan nyamuk dalam jumlah yang banyak, sehingga parasit bisa ditularkan ke orang lain. Kepadatan nyamuk sangat berkaitan dengan beberapa faktor biologi antara lain, daya fekunditas, kemampuan bertahan hidup, pertumbuhan dan perkembangan. Informasi tersebut dapat diperoleh dari tabel hidup yaitu tabel yang menyajikan tahap-tahap perkembangan nyamuk mulai dari tahapan telur hingga dewasa. Melalui tabel hidup, prediksi pertumbuhan dan penurunan populasi serangga (nyamuk) dapat diketahui. ${ }^{10}$

Penentuan strategi dan cara pengendalian serangga (nyamuk) sangat diperlukan data mengenai dinamika populasi yang dapat diketahui dari membuatan atau penyusunan tabel hidup. Sehubungan dengan hal tersebut maka diperlukan suatu pengembangan model popualsi yang lebih terinci dan realistis. Tabel hidup merupakan model populasi yang 
mampu memberikan informasi dasar mengenai kecepatan pertumbuhan populasi dalam suatu generasi (Ro), periode hidup (T).

Berdasarkan tabel hidup maka didapatkan informasi rinci mengenai potensi fekunditas. Fekunditas adalah banyaknya individu yang memasuki setiap tahap daur hidup dan banyaknya kematian pada setiap daur hidup. Kemampuan fekunditas dapat mempengaruhi nilai kecepatan reproduksi (Ro). Apabila $\mathrm{Ro}<1$ berarti terjadi penurunan populasi, sedangkan jika Ro $>1$ mengindikasikan adanya kenaikan jumlah populasi. ${ }^{8}$

Komponen-komponen dalam tabel hidup antara lain jumlah individu yang hidup pada kelompok umur $\mathrm{x}\left(\mathrm{I}_{\mathrm{x}}\right)$. Jumlah individu yang mati atau angka kematian pada masing-masing kelompok umur $(\mathrm{dx})$. Proporsi individu yang mati pada kelompok umur $\mathrm{x}$ terhadap jumlah individu dan hidup pada kelompok umur $\mathrm{x}$ atau laju kematian $\left(\mathrm{q}_{\mathrm{x}}\right)$. Keperidian spesifik individu pada individu kelompok umur $\mathrm{x}$ atau jumlah anak (betina) per kapita yang lahir pada kelompok umur $\mathrm{x}\left(\mathrm{m}_{\mathrm{x}}\right)$. Rata-rata individu pada kelas umur $\mathrm{x}$ dan kelas umur berikutnya, $\mathrm{x}+1\left(\mathrm{~L}_{\mathrm{x}}\right)$. Jumlah individu yang hidup pada kelas umur $\mathrm{x}=0 \ldots \mathrm{w}\left(\mathrm{T}_{\mathrm{x}}\right)$ dan harapan hidup individu pada setiap kelas umur $\mathrm{x}$ $\left(\mathrm{e}_{\mathrm{x}}\right)$. Melalui komponen-komponen tersebut, dapat diprediksi pertumbuhan serangga (nyamuk) pada masa yang akan datang.

Penelitian tabel hidup $C x$. quinquefasciatus masih sangat terbatas di Indonesia. Untuk menjelaskan lebih jauh tentang biologi $C x$. quinquefasciatus dan beberapa parameter kehidupan demografi lainnya, maka akan dilakukan penyusunan tabel hidup skala laboratorium. Data ini bermanfaat untuk dasar informasi upaya pengendalian vektor yang lebih efektif dan penyediaan nyamuk secara massal dalam aplikasi Teknik Serangga Mandul (TSM) di lapangan.

Berdasarkan fakta yang telah diuraikan di atas, penelitian ini bertujuan untuk mendiskripsikan aspek biologi yang meliputi masa inkubasi, ekslosi, eksdisis, ketahanan hidup, harapan hidup, laju reproduksi, dan waktu generasi pada skala laboratorium.

\section{MATERI DAN METODE \\ Strain nyamuk $C x$. quinquefasciatus}

Penelitian dimulai dengan melakukan survei larva $C x$. quinquefasciatus di Kelurahan Pabean Kota Pekalongan. Larva dilakukan identifikasi dan kolonisasi di laboratorium entomologi Balai Penelitian dan Pengembangan Pengendalian Penyakit Bersumber Binatang (Litbang P2B2) Banjarnegara. Suhu udara $25-28^{\circ} \mathrm{C}$ dengan kelembaban $75 \%$. Sampel penelitian nyamuk generasi F1 dan F2.

\section{Pengumpulan telur Culex quinquefasciatus}

Nyamuk betina gravid atau penuh darah dimasukkan ke dalam kandang bugdom ukuran $30 \mathrm{~cm}$ x $30 \mathrm{~cm}$ x $30 \mathrm{~cm}$ yang didalamnya telah berisi tembikar dari tanah liat yang berisi air jerami $10 \%$ sebagai tempat untuk bertelur serta kapas yang mengandung air gula sebagai makanan yang diletakkan pada botol. Air gula setiap dua hari sekali diganti dengan yang baru. Setelah 2-3 hari nyamuk betina akan meletakkan telurnya pada tembikar secara bergerombol membentuk sebuah rakit, yang setiap rakitnya jumlah telurnya bervariasi.

\section{Penetasan telur menjadi larva}

Telur dari wadah tembikar dipindahkan dalam tray ukuran $27 \mathrm{~cm} \times 35 \mathrm{~cm}$ x $5 \mathrm{~cm}$. Setiap tray berisi $5-$ 6 rakit. Telur akan menetas setelah 1-2 hari. Air yang digunakan untuk kehidupan nyamuk pradewasa adalah air rendaman jerami konsentrasi 10\% dengan volume $\pm 1,5$ liter. Pengamatan pada telur yang menetas menjadi larva instar I dilakukan setiap 24 jam. Perhitungan penetasan telur dilakukan pada tiga kelompok.

\section{Pemeliharaan larva $C x$. quinquefasciatus}

Larva instar I dan II diberi makan menggunakan makanan anjing yang ditumbuk (Pedigree $\left.{ }^{\circledR}\right)$ yang banyaknya disesuaikan dengan ukuran instar ditetaskan dalam wadah yang terbuat dari tanah (tembikar). Pemberian pakan dilakukan satu kali sehari. Pada larva instar III dan IV pakan (tidak ditumbuk) diberikan dua kali yaitu pagi dan sore hari. Larva yang telah menjadi instar pupa dari tempat pembiakan diambil dengan pipet lalu ditempatkan dalam wadah plastik kecil dan dimasukkan ke dalam kandang nyamuk.

\section{Pemeliharaan nyamuk $C x$. quinquefasciatus}

Larva yang telah menjadi pupa kemudian dipindah dengan menggunakan pipet ke dalam wadah plastik ukuran diameter bawah $4,5 \mathrm{~cm}$ bagian atas $6,5 \mathrm{~cm}$, tinggi $6,5 \mathrm{~cm}$ dan diberi air $\pm 50 \mathrm{ml}$. Wadah berisi pupa diletakkan dalam kandang bugdom ukuran $30 \mathrm{~cm} \times 30 \mathrm{~cm} \times 30 \mathrm{~cm}$. Pada umumnya setelah dua hari pupa akan berubah menjadi nyamuk. Bahan makanan nyamuk betina dan jantan diberikan larutan air gula $10 \%$ yang ditaruh dalam kapas dan diletakkan dalam botol. Nyamuk akan melakukan kopulasi didalam kandang selama 2-3 hari. Nyamuk betina akan menghisap darah marmot untuk proses pematangan telur. Sedangkan nyamuk jantan akan mengisap cairan gula $10 \%$. Setelah 2-3 hari mengisap darah nyamuk betina akan meletakkan telur pada tembikar. Pengamatan dilakukan terus menerus sampai nyamuk betina mati sehingga diperoleh tabel kehidupannya.

\section{Pembuatan larutan gula 10\%}

Bahan pakan nyamuk dewasa berupa larutan gula $10 \%$ yang dibuat dengan melarutkan $1 / 4$ sendok kecil gula ke dalam $100 \mathrm{ml}$ air putih kemudian ditambahkan 3-4 tetes vitamin, masukkan dalam botol plastik diberi kapas sebagai sumbu untuk menaikkan air gula ke atas. 


\section{Analisa Data}

Data perkembangan hidup diolah berdasarkan persentase. Perumusan tabel hidup spesies nyamuk Cx. quinquefasciatus didasarkan menurut Tarumingkeng (1994). ${ }^{8} \quad$ Parameter-parameter demografi yang akan dihitung pada penelitian ini meliputi :

Laju reproduksi kotor $(\mathrm{GRR})=\sum \mathrm{m}_{\mathrm{x}}$

Laju reproduksi bersih $\left(\mathrm{R}_{\mathrm{o}}\right) \quad=\sum \mathrm{l}_{\mathrm{x}} \mathrm{m}_{\mathrm{x}}$

Waktu generasi $(\mathrm{T}) \quad=\sum \mathrm{x} 1_{\mathrm{x}} \mathrm{m}_{\mathrm{x}} / \sum \mathrm{1}_{\mathrm{x}} \mathrm{m}_{\mathrm{x}}$

Laju pertumbuhan intrinsik $\left(\mathrm{r}_{\mathrm{m}}\right)=\ln \mathrm{R}_{\mathrm{o}} / \mathrm{T}$

Keterangan:

$\mathrm{x}=$ kelas umur kohort (hari)

$\mathrm{l}_{\mathrm{x}}=$ proporsi individu yang bertahan hidup pada umur $\mathrm{x}$

$\mathrm{m}_{\mathrm{x}}=$ jumlah keturunan betina yang dihasilkan dari induk betina pada umur $\mathrm{x}$

Nilai $\mathrm{m}_{\mathrm{x}}$ dihitung sebagai $\mathrm{m}_{\mathrm{x}}=\mathrm{E}_{\mathrm{x}} \mathrm{s}$, dimana $\mathrm{E}_{\mathrm{x}}$ adalah jumlah rata-rata telur yang dihasilkan per nyamuk betina pada umur $\mathrm{x}, \mathrm{s}$ adalah proporsi telur betina (diasumsikan sama dengan 0.5 ). ${ }^{11}$

\section{HASIL DAN PEMBAHASAN}

Siklus hidup $C x$. quinquefasciatus termasuk sempurna dengan melalui tahap telur, larva, pupa dan dewasa. Tahap telur sampai pupa termasuk fase akuatik sementara nyamuk dewasa pada fase terestrial. Perkembangan tahapan telur sampai menjadi nyamuk dewasa ditunjukkan pada tabel 1 .

Sampel telur pada penelitian ini termasuk dalam kategori baik. Hal ini ditunjukkan dengan masa inkubasi yang diperlukan untuk penetasan telur $C x$. quinquefasciatus rata-rata 2,07 hari dengan nilai daya tetas $97,5 \%$. Hasil penelitian ini berbeda dengan Manimegalai and Sukanya (2014) yang menunjukkan bahwa telur $C x$. quinquefasciatus menetas dalam waktu 3,8 hari. ${ }^{7}$ Penetasan telur berkaitan dengan perkembangan embrio yang dipengaruhi faktor lingkungan dan faktor genetik yang secara mutlak mengendalikannya. ${ }^{12}$ Telur yang tidak dibuahi, mengakibatkan telur yang dikeluarkan tidak akan menetas. ${ }^{13}$ Faktor lain yang berpengaruh adalah suhu air, suhu dan kelembaban udara serta intensitas cahaya tempat dimana telur akan menetas. Suhu dan kelembaban udara di Laboratorium Entomologi Balai Litbang P2B2 Banjarnegara berkisar antara \pm 21,3$28,2^{\circ} \mathrm{C}$ dengan kelembaban $\pm 55-79 \%$. Suhu dan kelembaban tersebut masih termasuk dalam kisaran suhu dan kelembaban optimum. Suhu optimum untuk pertumbuhan nyamuk berkisar antara $20^{\circ} \mathrm{C}-30^{\circ} \mathrm{C}$. Sementara kelembaban udara yang disukai nyamuk yaitu $60-80 \%{ }^{14}$ Nyamuk dapat bertahan hidup pada suhu rendah $\left(10^{\circ} \mathrm{C}\right)$, tetapi metabolismenya menurun atau bahkan terhenti bila suhunya turun sampai dibawah suhu kritis $4,5^{\circ} \mathrm{C}$. Pada suhu yang lebih tinggi dari $35^{\circ} \mathrm{C}$ juga mengalami perubahan dalam arti lebih lambatnya proses-proses fisiologis bahkan dapat meningkatkan mortalitas nyamuk. ${ }^{15}$ Selain itu suhu udara mempengaruhi perkembangan parasit dalam tubuh nyamuk, tingkat menggigit, istirahat dan perilaku kawin, penyebaran dan durasi siklus gonotrophik. $^{16}$

Suhu air yang dipakai dalam penelitian ini berkisar $24,5{ }^{\circ} \mathrm{C}-27,9{ }^{\circ} \mathrm{C}$. Suhu air optimal untuk perkembangan embrio dan penetasan telur berkisar $23,8^{\circ} \mathrm{C}$ sampai $29,4^{\circ} \mathrm{C} .^{17}$ Variasi dan peningkatan kelembaban berpengaruh kuat pada reaksi biologis, nyamuk $C x$. quiquefasciatus menunjukkan reaksi korelasi positif pada perubahan kelembaban. Pada kelembaban lebih dari $95 \%$, terjadi perubahan pada kemampuan nyamuk betina saat mencari pakan yaitu menghisap darah, yang berpengaruh pada pematangan ovari, menurunkan jumlah kemunculan nyamuk betina muda, dan pelemahan kondisi nyamuk betina saat kondisi lapar. ${ }^{18,19}$

Hasil pengamatan rata-rata telur yang tidak menetas mencapai $23,5 \%$. Kondisi telur yang tidak menetas, ada kemungkinan yang berembrio dan tidak berembrio. Telur yang tidak berembrio kemungkinan tidak dibuahi oleh sperma. Menurut Beaty dan Marguardt dan Said kondisi ini dapat disebabkan beberapa kemungkinan diantaranya tidak terjadinya kopulasi, nyamuk jantan tidak mengeluarkan sperma, sperma tidak tersimpan dalam spermateka, sperma tidak dapat keluar dari spermateka, sperma tidak dapat masuk kedalam telur melalui mikrofil atau sperma mati sebelum membentuk zigot. ${ }^{12,13}$

Masa inkubasi $C x$. quinquefasciatus rata-rata $2,07 \pm 0,59$ hari dengan persentase telur yang menetas sebesar 97,5\%. Larva instar I yang berhasil melanjutkan pertumbuhannya ke instar larva II hanya $75,9 \%$. Ada kecenderungan peningkatan persentase larva yang berhasil melanjutkan pertumbuhannya ke instar berikutnya (larva instar II-IV). Peluang terbesar larva instar IV menuju pupa terjadi penurunan persentase $(96,1 \%)$.

Laju ketahanan hidup atau survival rate (SR) fase akuatik dari $C x$. quinquefasciatus mengalami masa rentan pada fase instar I ke instar II $(75,87 \%)$, sedangkan pada fase akuatik selanjutnya termasuk tinggi yakni diatas 90\% (Gambar 1). Hal ini dikarenakan larva instar I masih sangat lemah, dan belum beradaptasi dengan lingkungan air sehingga angka kematiannya tinggi. Pada tahap selanjutnya larva telah mengalami adaptasi dan pemberian pakan dogfood (pedigree) mendukung perkembangan nyamuk $C x$. quinquefasciatus.

Pada instar III ke IV adalah waktunya larva sedang rakusnya makan dan terjadinya persaingan pangan. Kematian $C x$. quinquefasciatus pada stadium ini relatif kecil yaitu sebesar 1,6\%. Hal ini menunjukkan bahwa pemberian pakan mencukupi dan sesuai dengan kepadatan larva. Pada penelitian ini menggunakan baki ukuran $27 \mathrm{~cm} \times 35 \mathrm{~cm} \times 5 \mathrm{~cm}$, berisi 250 larva. Larva atau pupa yang terlalu padat di habitatnya, akan mengakibatkan persaingan intraspesifik untuk memperebutkan tempat dan makanan. ${ }^{20}$ Kondisi ini akan berpengaruh pada 
perkembangan stadium berikutnya. Pada larva instar 4 ukuran tubuhnya sudah besar dan kemampuan untuk bertahan hidup lebih baik, apabila dibandingkan dengan instar larva instar 1-3. Hal ini ditunjukkan dengan tingkat kematian larva stadium 4 yang relatif kecil yaitu $0,8 \%$.

Perkembangan larva lebih lanjut akan menjadi pupa setelah 12,2 hari (gambar 3.2). Pupa merupakan stadium akhir pada fase akuatik. Periode pupa ini tidak memerlukan makan, tetapi bukan berarti tidak ada proses kehidupan. Pupa tetap memerlukan zat asam yang masuk ke dalam tubuhnya melalui corong pemafasan. Apabila pupa ini mendapat rangsangan dari permukaan air maka pupa ini akan menyelam yang dibantu oleh alat pendayung pada abdomen dari pupa ini. ${ }^{9}$ Persentase kematian pupa rata-rata mencapai 3,9\% dan lama periode pupa mencapai 2,2 hari (Tabel 1). Instar pupa memerlukan waktu untuk berkembang menjadi nyamuk dewasa sekitar 2-3 hari, hal yang sama terjadi pada Aedes dan Anopheles. Tingginya rata-rata kematian pada stadium pupa dibandingkan stadium 4, kemungkinan diakibatkan adanya pupa yang mati tetapi tidak segera diambil sehingga menutupi permukaan air

Eksklosi merupakan persentase kemampuan pupa menjadi dewasa yaitu sebesar 96,06\%. Nilai ekdisis didapatkan sebesar 70,2\% yaitu dihitung berdasarkan larva yang berhasil menjadi pupa dibandingkan dengan jumlah larva yang sudah menetas dari satu kelompok yang sama.

Tabel 1 Perkembangan tahapan telur sampai menjadi nyamuk dewasa Cx. quinquefasciatus dalam kondisi laboratorium

\begin{tabular}{lclc}
\hline \multicolumn{1}{c}{ Parameter } & Jml Hari+ SD & \multicolumn{1}{c}{ Indikator } & Persentase \\
\hline $\begin{array}{l}\text { Masa inkubasi } \\
\text { Lamanya instar larva }\end{array}$ & $2,07 \pm 0,59$ & Telur menetas & 97,5 \\
- Instar 1 - instar 2 & $2,6 \pm 0,45$ & Jumlah larva instar 2 & \\
- Instar 2-instar 3 & $2,4 \pm 0,30$ & Jumlah larva instar 3 & 75,9 \\
- Instar 3 - instar 4 & $2,7 \pm 0,51$ & Jumlah larva instar 4 & 94,9 \\
- Instar 4 - pupa & $2,5 \pm 0,43$ & Jumlah pupa & 98,4 \\
- Pupa - dewasa & $2,2 \pm 0,21$ & Kemunculan menjadi nyamuk & 99,2 \\
Eksklosi & & & 96,1 \\
Eksdisis & & & 96,06 \\
\hline
\end{tabular}

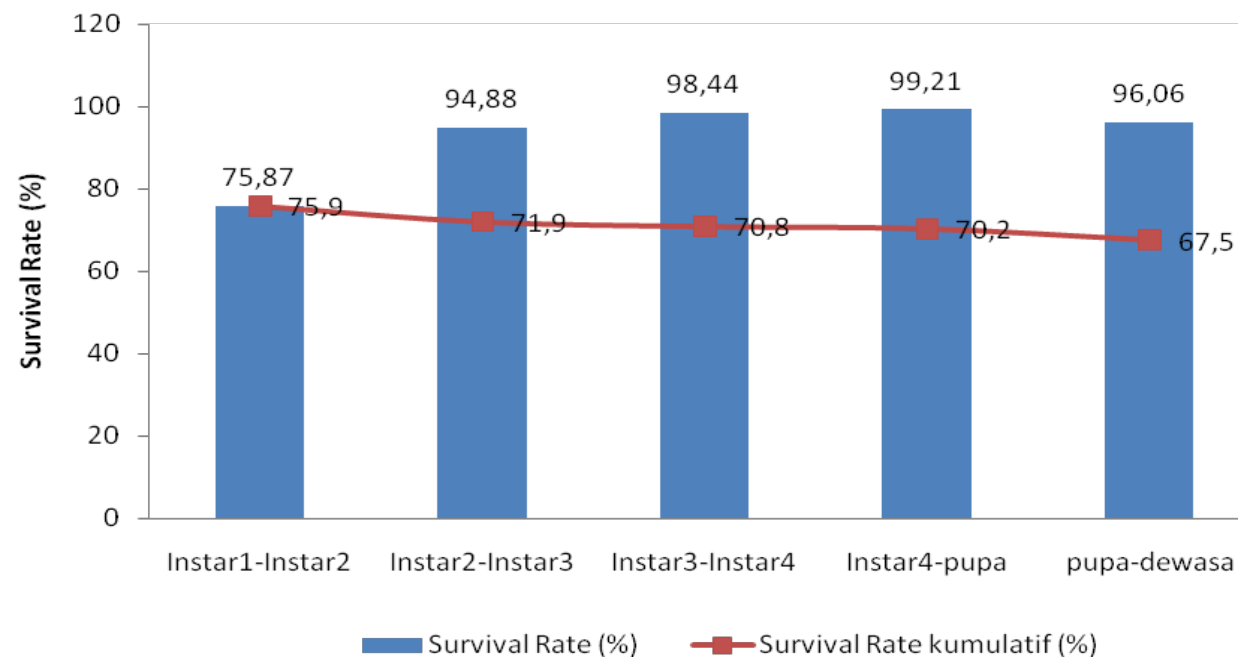

Gambar1. Ketahanan hidup fase akuatik Culex quinquefasciatus kondisi laboratorium

Fase akuatik nyamuk dapat dianalisis dari nilai laju ketahanan hidup tiap fase akuatik dan laju ketahanan hidup kumulatif. Data tersebut disajikan pada Gambar 1. Laju ketahanan hidup atau survival rate (SR) fase akuatik dari $C x$. quinquefasciatus mengalami masa rentan pada fase instar 1 ke instar $2(75,87 \%)$, sedangkan pada fase akuatik selanjutnya termasuk tinggi yakni diatas $90 \%$. Hal ini dikarenakan larva instar 1 masih sangat lemah, dan belum beradaptasi dengan lingkungan air sehingga angka kematiannya tinggi. 
Pada tahap selanjutnya larva telah mengalami adaptasi dan pemberian pakan dogfood (pedigree) mendukung perkembangan nyamuk $C x$. quinquefasciatus. Pada instar 3 ke 4 adalah waktunya larva sedang rakusnya makan dan terjadinya persaingan pangan. Kematian $C x$. quinquefasciatus pada stadium ini relatif kecil yaitu sebesar $1.6 \%$. Hal ini menunjukkan bahwa pemberian pakan mencukupi dan sesuai dengan kepadatan larva. Pada penelitian ini menggunakan baki ukuran $27 \mathrm{~cm} \times 35 \mathrm{~cm}$ x $5 \mathrm{~cm}$, berisi 250 larva. Larva atau pupa yang terlalu padat di habitatnya, akan mengakibatkan persaingan intraspesifik untuk memperebutkan tempat dan makanan. ${ }^{20}$ Kondisi ini akan berpengaruh pada perkembangan stadium berikutnya. Pada larva instar 4 ukuran tubuhnya sudah besar dan kemampuan untuk bertahan hidup lebih baik, apabila dibandingkan dengan instar larva instar 1-3. Hal ini ditunjukkan dengan tingkat kematian larva stadium 4 yang relatif kecil yaitu $0,8 \%$.

Laju ketahanan hidup kumulatif fase akuatik Cx. quinquefasciatus berkisar antara $67,5 \%-75,9 \%$. Data menunjukkan laju ketahanan hidup kumulatif mengalami penurunan dari instar 1 sampai menjadi dewasa. Ketahanan hidup kumulatif $C x$. quinquefasciatus fase akuatik dari instar 1 ke instar 2 sebesar $71,0 \%$ kemudian menurun pada instar ke 3 $(70,0 \%)$ naik sedikit menuju fase pupa $(70,2 \%)$ dan menurun kembali saat menjadi nyamuk dewasa $(67,5 \%)$. Hal ini menunjukkan dari total telur nyamuk yang ada maksimal hanya $75 \%$ yang dapat berkembang sampai menjadi dewasa. Hasil ini berbeda dengan penelitian Iswanto (2014), $C x$. quinquefasciatus yang berasal dari Yogyakarta mempunyai ketahanan hidup sampai $80,4 \%$ sementara dari Semarang 82,6\%. Perbedaan ini lebih dikarenakan faktor internal atau faktor yang berasal dari dalam tubuh larva dan juga faktor eksternal. Kelembaban udara pada penelitian tersebut relatif lebih tinggi $(72,0 \% \quad-96,0 \%)$. Kondisi ini kemungkinan mengakibatkan ketahanan hidup pada fase akuatik lebih bertahan lama. Hal ini berakibat semakin banyak larva yang berpeluang hidup sampai menjadi dewasa.

Gambar 2 menunjukkan ketahanan hidup fase dewasa Culex quinquefasciatus jantan dan betina. Laju ketahanan hidup nyamuk jantan $C x$. Quinquefasciatus cenderung lebih pendek dibandingkan nyamuk betina. Laju ketahanan perhari pada nyamuk jantan tertinggi $(>90 \%)$ terjadi hari ke1 sampai hari ke-5, sementara pada nyamuk betina hari ke-1 sampai hari ke-8. Laju ketahanan hidup kumulatif nyamuk mencapai $0 \%$ pada hari ke-23 pada nyamuk jantan dan 33 nyamuk betina. Hal ini menunjukkan umur nyamuk $C x$. quinquefasciatus jantan yang dikembangbiakkan di laboratorium adalah 23 hari, sementara betina sampai 33 hari. Ada perbedaan umur nyamuk pada spesies yang lain, $A n$. aconitus umur nyamuk betina mencapai 25,6 hari, $A n$. farauti 25,67 dan An. subpictus 18 hari. $^{9,21}$

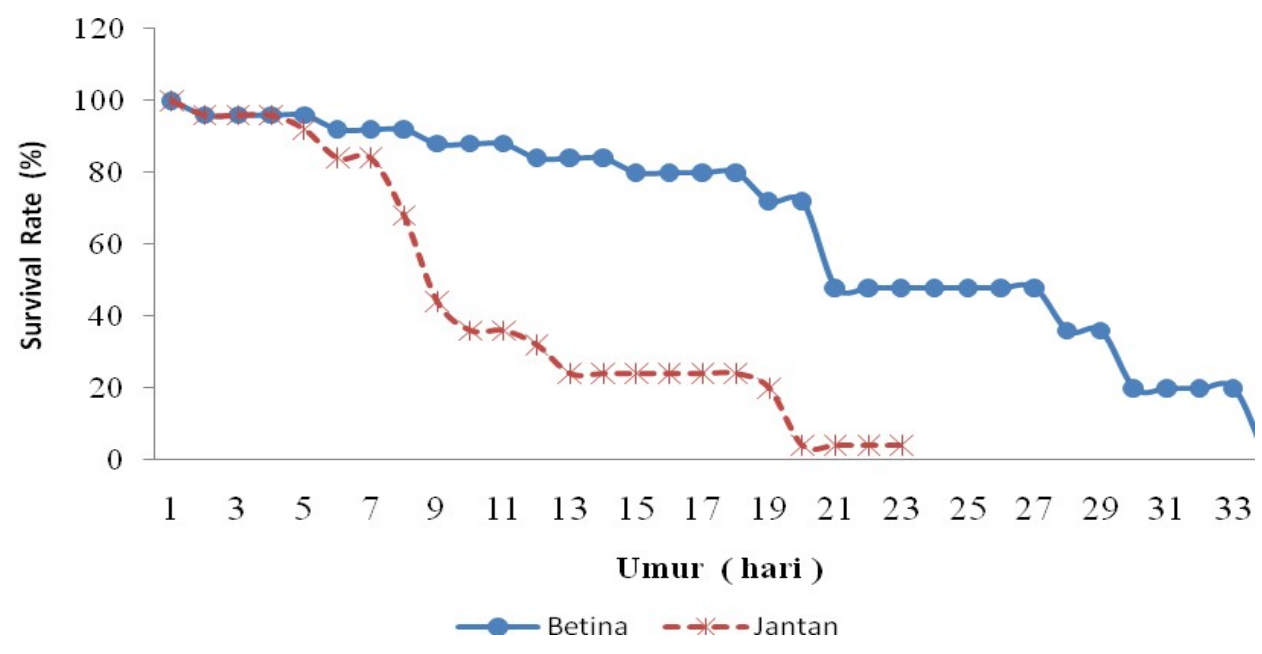

Gambar 2. Ketahanan hidup fase dewasa Cx. quinquefasciatus jantan dan betina di laboratorium

Waktu yang dibutuhkan setiap perubahan fase akuatik $C x$. quinquefasciatus ditunjukkan pada gambar 3. Waktu terlama yang dibutuhkan untuk pertumbuhan terjadi pada instar $3 \mathrm{ke}$ instar 4 . Sementara waktu terpendek pada saat pertumbuhan dari fase pupa menjadi nyamuk dewasa. Pertumbuhan pupa menjadi nyamuk terjadi pada hari ke 12,5. Tabel hidup Cx. quinquefasciatus ditunjukkan pada tabel 2 . Berdasarkan analisis tabel hidup didapatkan bahwa laju reproduksi kotor Cx. quinquefasciatus adalah 275,86 individu per generasi, laju reproduksi bersih (nilai $\mathrm{R}_{0}$ ) sebesar 196,75, waktu generasi 14,91 hari dan lahu pertumbuhan intrinsik 0,35 nyamuk per hari 


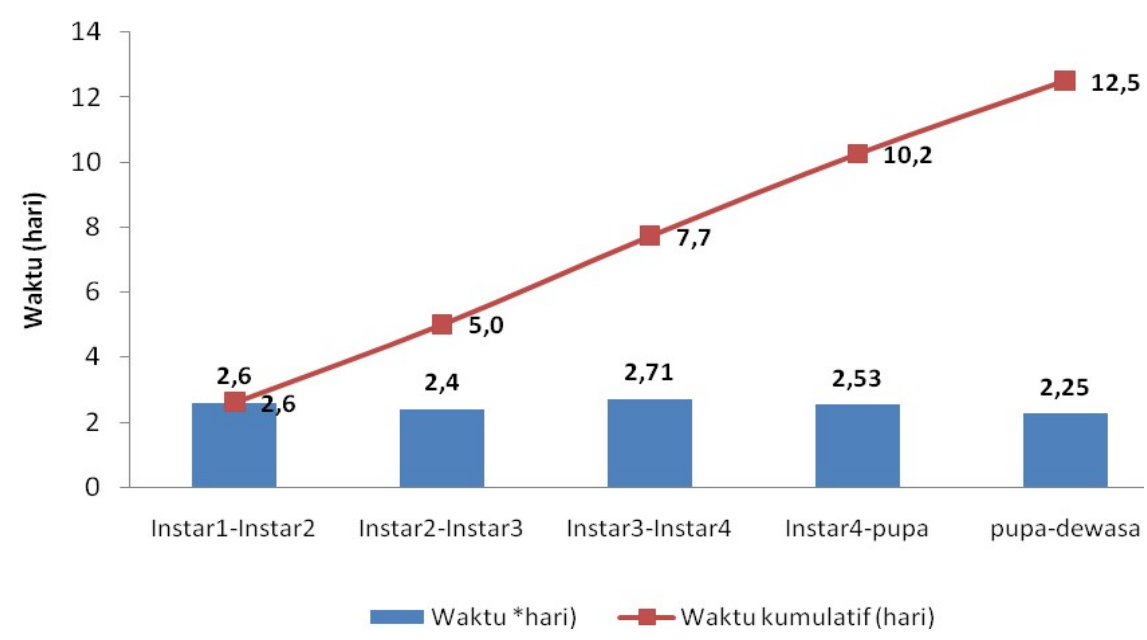

Gambar 3. Histogram waktu yang dibutuhkan dalam tiap perubahan fase pertumbuhan Culex quinquefasciatus kondisi laboratorium

Laju reproduksi kotor (GRR) menggambarkan rataan jumlah keturunan betina per induk yang dihasilkan oleh nyamuk $C x$. quinquefasciatus yang hidupnya mencapai umur maksimal. Berdasarkan analisis tabel hidup nyamuk $C x$. quinquefasciatus yang dapat mencapai umur 33 hari akan menghasilkan 275,86 nyamuk per generasinya.

Laju reproduksi bersih (Ro) didapatkan 196,75 yang menunjukkan bahwa rataan banyaknya keturunan betina yang dihasilkan oleh satu induk betina $C x$. quinquefasciatus adalah 196,75. Dari hasil yang diperoleh menunjukkan bahwa pada $C x$. quinquefasciatus dapat meningkat populasinya sebanyak 196,75 kali dari populasi pada generasi sebelumnya. Laju reproduksi dapat menggambarkan kesesuaian tempat perkembangbiakan.

Laju pertumbuhan intrinsik (rm) menunjukkan banyaknya keturunan betina yang dihasilkan oleh induk betina per hari. ${ }^{22}$ Dalam penelitian ini nilai $\mathrm{rm}$ adalah 0,35 nyamuk/hari.
Rataan masa generasi (T) adalah rataan waktu yang dibutuhkan suatu individu sejak telur diletakkan hingga saat imago betina menghasilkan separuh keturunannya. ${ }^{22}$ Hasil penelitian menunjukkan rataan masa generasi $C x$. quinquefasciatus adalah 14,91 hari. Dalam waktu 14,91 hari $C x$. quinquefasciatus betina mampu menghasilkan keturunan kembali. Nilai $\mathrm{T}$ yang semakin kecil maka semakin cepat waktu suatu organisme untuk tumbuh atau berkembangbiak. Hasil penelitian secara keseluruhan menunjukkan angka kelulusan hidup $C x$. quinquefasciatus tertinggi terjadi pada stadium pupa, diikuti stadium telur dan kemudian stadium larva. Sebaliknya angka kematian (mortalitas) tertinggi pada stadium larva, telur dan pupa. Jadi pertumbuhan populasi $C x$. quinquefasciatus secara alamiah diatur dan dikendalikan oleh kelulusan hidup dan mortalitas.

Tabel 2. Tabel hidup nyamuk Cx. quinquefasciatus di laboratorium

\begin{tabular}{lcl}
\hline \multicolumn{1}{c}{ Parameter } & \multicolumn{1}{c}{ Nilai } & \multicolumn{1}{c}{ Satuan } \\
\hline GRR & 275,86 & nyamuk/generasi \\
$\mathrm{R}_{\mathrm{o}}$ & 196,75 & nyamuk/induk/generasi \\
$\mathrm{T}$ & 14,91 & Hari \\
$\mathrm{r}_{\mathrm{m}}$ & 0,35 & nyamuk/hari \\
\hline
\end{tabular}

Keterangan; GRR= Laju Reproduksi Kotor; $\mathrm{R}_{\mathrm{o}}=$ Laju Reproduksi Bersih; $r \mathrm{rm}=$ Laju Pertumbuhan Intrinsik; $\mathrm{T}=$ Rataan Masa Generasi

\section{SIMPULAN}

Penelitian ini menyimpulkan: 1) $C x$. quinquefasciatus mempunyai empat fase dalam hidupnya yaitu telur, larva, nimfa dan imago. Nyamuk Cx. quinquefasciatus jantan berumur 21 hari dan betina 33 hari. 2) Pertumbuhan populasi $C x$. quinquefasciatus dikendalikan oleh tingkat kelulusan hidup dan mortalitas. 3) Laju produksi kotor (GRR) adalah 275,86 nyamuk/generasi, laju reproduksi bersih (Ro) adalah 196,75 nyamuk/induk/generasi, laju pertumbuhan intrinsik (rm) 0,35 nyamuk/ induk/hari dan rataan masa generasi $(\mathrm{T})$ adalah 14,91 hari. 


\section{DAFTAR PUSTAKA}

1. Arsin AA. Epidemiologi Filariasis Di Indonesia Masagena Press. 2016.110 p

2. Pusat Data dan Informasi Kementerian Kesehatan RI. Situasi Filariasis di Indonesia Tahun 2015. Buletin Infodatin 2016 ISSN 2442-7659

3. Bhattacharya S, Basu P. The Southern House Mosquito, Culex quinquefasciatus: profile of a smart vector. Journal of Entomology and Zoology Studies. 2016 Feb 7; 4(2): 73-81

4. Wulandari W. Model Pertumbuhan Hidup Nyamuk Aedes Aegypti. Jurnal Konvergensi. 2014 Oktober; 4(2):105-117

5. Volozina NV. The effect of the amount of blood taken and additional carbohydrate nutrition on oogenesis in female of blood-sucking mosquitoes of the genus Aedes (Diptera: Culicidae) of various weights and ages. Entomological Review. 1967(24):27-32

6. Clements AN. The Biology of Mosquitoes Volume 1 Development, Nutrition and Reproduction. USA : CABI Publishing. 2000.

7. Manimegalai K, Sukanya S. Biology of the filarial vector, Culex quinquefasciatus (Diptera: Culicidae). International Journal of Current Microbiology and Applied Science. 2014; 3(4): 718-724

8. Tarumingkeng RC. Dinamika populasi: kajian ekologi kuantitatif. Pustaka Sinar Harapan dan Universitas Kristen Krida Wacana, Jakarta 1994. $284 \mathrm{p}$.

9. Munif A, Ariati Y. Tabel kehidupan An. aconitus di laboratorium Jurnal Media Litbang Kesehatan. 2007; 17(2): 1-7

10. Erickson RA, Presley SM, Allen LJS, Long KR, Cox SB. A stage-structured, Aedes albopictus population model. Ecological Modelling. 2010 August 23; 221(9): 1273-1282.

11. Rozilawati, Mohd Masri S, Tanaselvi K, Mohd Zahari TH, Zairi J, Nazni WA, Lee H. Life table characteristics of Malaysian strain Aedes albopictus (Skuse). Journal Serangga Centre for Insects Systematic, University Kebangsaan Malaysia. 2017; 22(1): 85-121.

12. Beaty BJ, Marquardt WC. The Biology of Disease Vectors .1st Edition. Niwot,CO USA: University Press of Colorado. 1996.632 p.

13. Said MSM. Pengantar Entomologi. Percetakan Dewan Bahasa dan Pustaka. Kuala Lumpur 1983. $255 \mathrm{p}$.

14. Costa EAPdA, Santos EmdM, Correia JC, Albuquerque CMR, 2010. Impact of small variations in temperature and humidity on the reproductive activity and survival of Aedes aegypti (Diptera, Culicidae). Medical and Veterinary Entomology Revista Brasileira de Entomologia. 2010 Juli 5;54(3): 488-493

15. Alexander TC, Matacchiero AC, Kilpatrick AM, Laura DK. The Effect of Temperature on Life
History Traits of Culex Mosquitoes. Journal Medical Entomology. 2014 Januari; 51(1): 55-62

16. Widya HC, Suharyo. Dinamika Aedes Aegypti sebagai Vektor Penyakit. Jurnal Kesehatan Masyarakat. 2006 Desember; 2(1):40-50 .

17. Iswanto, Mardihusodo SJ, Baskoro T. Tabel kehidupan dan fekunditas Culex quinquefasciatus say (Diptera: Culicidae) Kota Yogyakarta dan Semarang di laboratorium. Jurnal Sain Kesehatan. 2004; 17(1):89-104

18. Thomson RCM. The Reactions of Mosquitoes to Temperature and Humidity. Bulletin of Entomological Research. 2009 Juli 10; 29(2): p5140.

19. Makara MWK, Philip M, Ngumbi, Lee DK. Effects of Temperature on the Growth and Development of Culex pipiens Complex Mosquitoes (Diptera: Culicidae). IOSR Journal of Pharmacy and Biological Sciences . 2015;10(6);p 01-10

20. Service MW. Mosquitoe ecology field : Sampling metode seconds edition. London. Springer El secier applaid science. 1993.

21. Munif A, Sukirno M, Mardiana. Tabel kehidupan An.farauti sebagai pendukung analisis epidemiologi penyakit tular vektor di laboratorium. Jurnal Media Litbang Kesehatan; $2005: 15(4): 12-19$

22. Birch LC. The intrinsic rate of natural increase of an insect population. Journal of Animal Ecology. 1948; 17 (1):15-26 